\title{
Construction waste management in a developing country: case study of Ipoh, Malaysia
}

\author{
S. A. Mahayuddin ${ }^{1}$, J. J. Pereira ${ }^{1}$, W. H. W. Badaruzzaman ${ }^{2}$ \\ \& M. B. Mokhtar ${ }^{1}$ \\ ${ }^{1}$ Institute for Environment and Development (LESTARI), Malaysia \\ ${ }^{2}$ Faculty of Civil Engineering, Universiti Kebangsaan Malaysia (UKM), \\ Malaysia
}

\begin{abstract}
Construction waste is a growing problem in both developing and developed countries, except that the nature of its generation and handling is country dependent. Developing countries are moving towards better construction waste management; however, there is still insufficient collection and improper disposal of construction waste. Construction waste represents large amounts of material that are often illegally dumped by roadsides, river banks and many other open spaces. This causes significant health and environmental problems as well as negative economic impacts on nearby properties. Urgent and immediate improvement of the construction waste disposal practices is necessary to meet the current demand for improved construction waste management. However, there is very little relevant information on disposal practices for construction waste at the municipal level, including its composition and the disposal site characteristics. A study has been conducted in Ipoh, one of the cities in Malaysia to fill the knowledge gap. The study focuses on construction waste disposal practices in the city, including the illegal dumping of construction waste. A survey has been conducted to investigate the construction waste disposed of at the legal and illegal dumpsites around the city. This paper presents a general overview of current construction waste management practices in Ipoh. It also describes the problems, issues and challenges faced by Ipoh based on the outcome of a recent study. This paper concludes with the identification of a series of potential ways to improve construction waste management at the municipal level.
\end{abstract}

Keywords: construction waste, waste management, disposal, illegal dumping. 


\section{Introduction}

The increase of construction activities due to development in developing countries increases the generation of construction waste. The traditional method for managing construction waste is to dispose of waste at a disposal site, or to burn or bury it at the construction site [1]. In Malaysia, it is common for construction waste to be dumped at the same site as municipal solid waste. This method is popular because it does not need proper planning or advanced technology. However, disposal of construction waste has great impact on the capacity of the disposal site, construction waste management cost and the environment [2]. Although most construction waste end up in landfills, there are still major quantities disposed of at illegal dumpsites [3]. Illegal dumping is a major problem in many areas which raises concerns with regard to safety, property value, and quality of life in the community [4].

In Malaysia, dumping of waste at illegal dumping sites is a common practice, particularly industrial and construction wastes. However, statistics on the quantities of solid waste dumped illegally is lacking $[5,6]$. Construction waste disposal practices need urgent and immediate improvement to meet the current demand for improved construction waste management. However, the relevant information on the disposal practices of construction waste such as waste composition and disposal site characteristics at the municipal level, is limited. This study has been conducted in Ipoh city in Malaysia, to fill the knowledge gap. In addition, the status of construction waste management is unknown due to the poor record of construction waste quantity disposed of at the municipal landfill. This means that the data concerning the amount of construction waste generated and disposed of are not readily available. This paper presents a general overview of current construction waste management practices in Ipoh and highlights the problems, issues and challeges faced by the local authority. A series of potential ways to improve waste management at the municipal level is also suggested in this paper.

\section{Heap survey}

Ipoh is the capital of Perak and is also an intermediate connective growth conurbation, located in the north of Peninsular Malaysia. In comparison to other areas in Perak, construction activities are higher in Ipoh due to its function as the main administrative centre. Ipoh covers an area of 387.63 square kilometres with a population of 562,500 and has been administered by the Ipoh City Council since 1988 [7].

The legal dumpsite for Ipoh is Bercham landfill at Tanjung Rambutan which is the largest landfill in Perak. It has been operated by MBI since 1983, with an area of 0.46 square kilometres (114 acres). This landfill is currently classified as a Level 2 Sanitary landfill, comprising a bund (embankment) and daily soil covering [8]. In 2006, the tipping fee was MYR20.00 per tonne. However, from several visits to the legal dumpsite it was found that the recorded quantities of construction waste were small despite the growing construction activities in 
Ipoh. Additionally, the construction companies are not legally obliged to record and report the quantitative characteristics of the generated waste. They are unable to provide reasonably reliable data. Thus, primary surveys are the only way to estimate the disposed quantity of construction waste at both legal and illegal dumpsites.

A waste heap survey was conducted in 14 of the 22 administrative zones of Ipoh. The selection of the zone was based on the level of residential development. The study site in Bercham is a legal dumping site for municipal and construction waste. All other sites are illegal and located at the outskirts of the Ipoh city centre. The sites contained mainly recognisable construction waste material which allowed visual estimation. These sites have similar characteristics to many illegal dumping sites $[4,9]$.

The survey adopted the visual volume based estimation method developed by Cascadia Consulting Group [10] based in California. LESTARI in Lembah Klang and NREB Sarawak in Sarawak also applied a similar method to estimate construction waste quantities [6]. The construction waste measured in the survey was classified based on the material classificaton by U.S. EPA [11] and Ireland EPA [12] for systematic and adequate estimation. The materials studied have been classified into ten major groups; namely wood, metal, concrete, bricks, tiles, cement, insulation materials, glass, gypsum board, and soil,aggregate and sand. All other materials are categorised as Others. All the expected construction waste was listed in a survey form. The form was used to record the estimated quantity of construction waste found in a waste heap. Each waste heap was considered as one sample and the particulars were recorded in different forms. The heap was identified by the heap form, types of waste found in the heap and the physical appearance of the construction waste. Then visual estimation was conducted for every sample by following these six procedures

- Estimate the total sample by observation of the whole site area to make sure all the potential samples were included in the survey

- Record the sample number and date on the survey form

- Measure and record the length, width and height of the sample to produce the sample volume

- Identify the types of construction waste present in the sample

- Estimate the composition by volume for each type of construction waste in the sample and record the percentage

- Check and reconcile percentage estimates of the construction waste to a total of $100 \%$

Based on the percentage by volume in a sample and density of each material, the weight of the construction waste was calculated by using eqn. (1) [10]. The average density for the materials was derived from previous studies by NOLAN ITU Density, Tchobanoglous Density, Golder Density [13] and LESTARI [6].

$$
c=s \times v \times d
$$

where:

$c=$ the total weight of specific construction waste in the sample

$s=$ percentage estimate of the material class, as a portion of all the material in the sample 
$v=$ total volume of the sample $\left(\mathrm{m}^{3}\right)$

$d=$ material density (tonne $/ \mathrm{m}^{3}$ )

The composition of specific construction waste refers to the ratio of construction waste's weight to the total sample weight at the survey site $\left(r_{j}\right)$. The estimation was calculated by using eqn (2) [10].

$$
\begin{gathered}
\mathrm{r}_{\mathrm{j}}=\sum_{i} c_{i j} \\
\sum_{i} w_{i}
\end{gathered}
$$

where:

$c=$ weight of particular material

$w=$ sum of all material weights

$i=1$ to $n$, where $n=$ number of selected samples

$j=1$ to $m$, where $m=$ number of materials

\section{Results and discussion}

The estimated quantity of construction waste disposed was calculated separately for the legal and illegal dumpsites. From the survey, only 9 tonnes of construction waste was estimated at the legal dumpsite, compared to 12351 tonnes disposed of at the illegal dumpsites. At the legal dumpsite, only five types of construction waste were recorded, with the largest composition by weight being insulation material for ceiling (38\%). This is followed by surplus lime $(27 \%)$, metal $(25 \%)$, glass $(9 \%)$, and wood (1\%) as shown in fig. 1 .

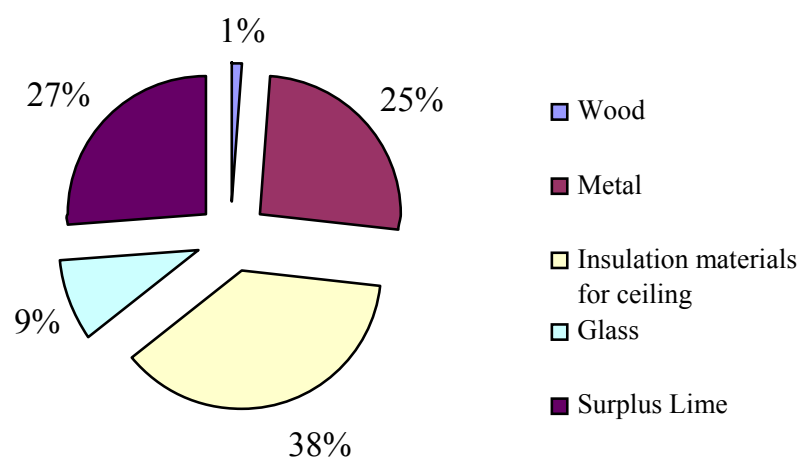

Figure 1: $\quad$ Construction waste composition disposed of at MBI dumpsite.

Meanwhile, almost all types of construction waste were found at the illegal dumpsites. The largest composition was soil, aggregate, and sand (43.82\%). This was followed by concrete $(27.03 \%)$ and bricks $(24.17 \%)$. The overall composition of construction waste found at the illegal dumpsites is shown in fig. 2 . 


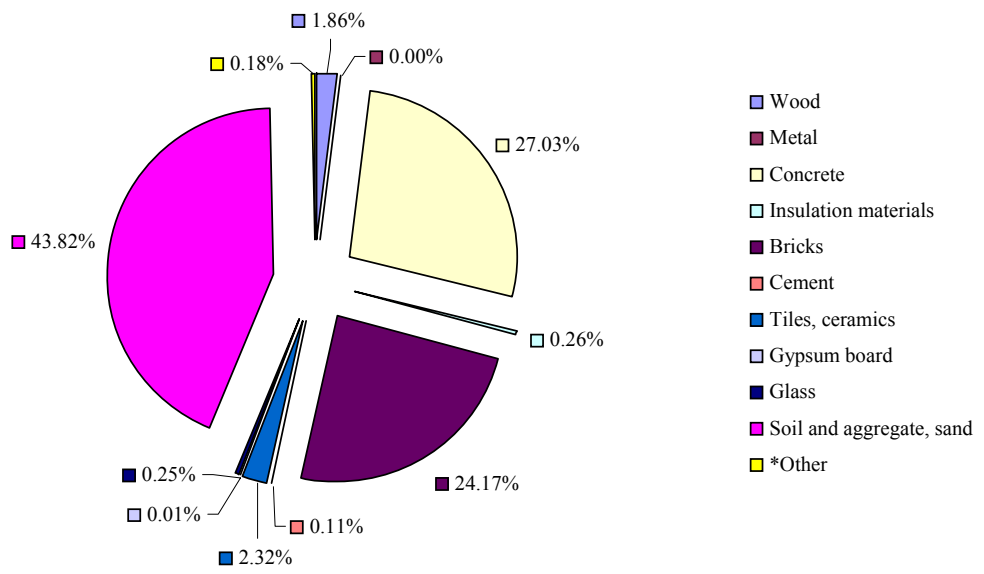

Figure 2: Construction waste composition disposed of at illegal dumpsites. (*Other: Plastic, surplus lime, packaging products, tarred material and mixed residue.)

The estimated quantity of construction waste disposed of at the illegal dumpsites was found to be higher than that at the legal dumpsite. This indicates that illegal dumping of construction waste is a common practice among local contractors. There is evidence of illegal dumping in many places such as vacant land, dead-end roads, road reserves, former mining areas and bushes. The disposal of large quantities of construction waste is also a reflection of poor management by the construction sector, as disposal is the least desired practice in the waste management hierarchy. It also signifies that lawmakers may have given at least some members of the industry the perception that no other viable disposal alternative is available [14]. Illegal dumping is the greatest challenge Ipoh is facing in improving construction waste management at the municipal level. Among the issues that have been identified are; insufficiently stringent legislation, lack of enforcement, inadequate facilities, lack of a collection network, and low levels of awareness and the negative attitudes of communities. A series of potential ways to improve construction waste management has been identified for construction waste disposal at the municipal level.

\subsection{Insufficiently stringent legislation}

Studies of the relevant legislation show that regulations for the disposal of construction waste in Ipoh have not been as stringent as those for municipal solid wastes. Like other places, various laws and regulations have been provided to regulate the negative impacts caused by the construction industry, including the generation of pollution. Unfortunately, only partial success has been attained. For example, Singapore imposes a fine of up to $\mathrm{S} \$ 50,000$ on conviction of illegal dumping and $\mathrm{S} \$ 50,000$ for repeat offenders and imprisonment for up to 12 
months [15]. The introduction of stricter measures, such as taxation and disposal have proven effective in some European countries. Therefore, MBI should revise the by-law to incorporate stiffer penalties and hire more enforcement officers to investigate and enforce regulations to prevent dumpers utilising streamlined administrative procedures. In addition, clearer legislation and rules on the disposal of construction waste should be provided to allow and encourage contractors to manage waste in a more environmentally friendly manner.

\subsection{Lack of enforcement}

Enforcement is a common issue in the management of solid waste $[2,16,17]$. Some problems in enforcement are lack of empowerment, insufficient manpower, lack of trained enforcement officers and local authorities that do not have enough funds to support enforcement efforts [17]. However, better enforcement by the local authority if combined with more stringent legislation would have a satisfying outcome in construction waste management. By addressing the problems identified, the MBI officers can monitor the construction waste disposal by the contractors more often to ensure that all the construction waste is disposed of at the allocated site. The monitoring can be done either by site visits or by a disposal control system.

\subsection{Inadequate facilities}

Another problematic issue is inadequate facilities for the disposal of construction waste. The legal dumpsite is not properly manned and does not provide a proper programme for the recycling of construction waste or any differentiation of the construction waste disposed. These wastes are regularly disposed of at the same disposal site as other solid waste resulting in a mixture of inert and organic materials at the landfill. Land filling of construction waste is unsound and impractical, both economically and environmentally because some of these wastes are recyclable and reusable. Therefore an introduction and promotion of recycling facilities and buy-back centres of construction waste can reduce the quantity of construction waste disposed of at the dumpsite. Construction companies should be obliged to record and report the quantity of waste they generate.

\subsection{Lack of collection network}

Generally, there is an absence of a network for the collection and utilisation of materials contained in the construction waste generated. The lack of a collection network and insufficient collection of waste from construction sites contributes to illegal dumping. This is shown by piles of waste by roadsides, river banks and many other open spaces found during the survey. In fact, some local authorities handle all solid waste such as industrial, market, domestic, and construction waste as if they are the same and collect them together [17]. A proper collection system and network is urgently needed to overcome this problem. Appointment of construction waste disposal contractors by the local authority as practiced in 
Klang Valley can ensure that all the construction wastes generated is sent to legal dumpsites.

\subsection{Awareness and attitudes}

Another issue that needs to be considered to improve the management of construction waste disposal is the awareness and attitude of the communities involved in the construction sector such as the construction industry, local authority and local people. Negative attitude towards subordinates, attitudinal differences between different working groups, and lack of training to reinforce the importance of waste minimisation practices have obstructed proper waste management practices in the industry [18]. The easy availability of raw materials for building construction in Ipoh makes this matter even harder to deal with. However, the implementation of training programmes to provide essential knowledge about good practices and the reinforcement of important messages may develop positive attitudes among the players. A tool box talk as exercised in the UK could be used as a good example for the dissemination of knowledge to the site workers.

\section{Conclusion}

The Ipoh City Council requires that construction waste be disposed of at legal landfills. However, very little construction waste was recorded there during the study. Illegal dumping was found to be a common practice. This scenario has the potential to cause significant health and environmental problems and decrease the value of nearby properties. The negligent behaviour of local contractors is due to lack of proper construction waste control and monitoring by the City Council. The City Council faces many challenges to manage construction waste disposal. These include insufficiently stringent legislation, poor enforcement, inadequate facilities and collection network, low public awareness and lack of capacity.

Improvements should begin with the revision of legislation to make it more stringent, with guidelines on safe disposal of construction waste. This should include a requirement for contractors to record the composition and quantity of construction waste generated, for better control. These measures should be coupled with better enforcement by the City Council with regular monitoring and site visits. The City Council can also play an important role in promoting good practices in construction waste management. For example, the introduction and promotion of recycling facilities and buy-back centres for construction waste can reduce the quantity of construction waste disposed off at the dumpsite. Recycling programmes should be promoted by private and public authorities.

For a recycling programme to succeed it has to be supported by a proper collection system with wide coverage and sufficient number of registered disposal contractors. The implementation of training programmes to provide essential knowledge about good practices will help to inculcate a positive attitude among contractors. An effective information dissemination program is also required for this purpose. The improvement of construction waste 
management needs to be addressed in a holistic and systematic manner, with the cooperation of all the parties involved.

\section{Reference}

[1] Symonds, Construction and Demolition Waste Management Practices and their Economic Impacts, report to DGXI, 1999.

[2] Nabil Kartam, Nayef Al-Mutairi, Ibrahim Al-Ghusain \& Jasem AlHumoud, Environmental management of construction and demolition waste in Kuwait. Waste Management, 24(10), pp. 1049-1059, 2004.

[3] Fatta, D., Papadopoulos, A., Avramikos, E., Sgourou, E., Moustakas, K., Kourmoussis, F., Mentzis, A., and Loizidou, M., Generation and management of construction and demolition waste in Greece-an existing challenge. Resources, Conservation and Recycling, 40, pp. 81-91, 2003.

[4] United States Environmental Protection Agency (USEPA), Region 5, Illegal dumping prevention guidebook. EPA905-B-97-001. 1998.

[5] Ministry of Housing and Local Government (MHLG). National Strategic Plan for Solid Waste Management. Volume 2 Main Report. Malaysia. 2005.

[6] LESTARI, Construction waste management: Waste minimisation and recycling potential of construction materials. Milestone Report 4 CIDBLESTARI, 2005.

[7] JPBD Perak, Draf Rancangan Struktur Ipoh (Penggubahan) 1998-2020, 1998.

[8] Idris, A., Hassan, M.N. \& Inanc, B, Overview of waste disposal and landfills/dumps in Asian countries. Material Cycles and Waste Management, 6, pp. 104-110, 2004.

[9] Zolkifly Che Din, Pengurusan sampah sarap perbandaran: Isu, masalah dan pengalaman Majlis Perbandaran Pulau Pinang. Policies to improve Municipal Solid Waste Management, eds. Siwar, C., Ali, H., Ahmad, A.R. \& Hamid, M.Z.A, LESTARI: UKM, pp. 27-40, 2001.

[10] Cascadia Consulting Group, Targeted Statewide Waste Characterization Study: Detailed Characterization of Construction and Demolition Waste, Intergrated Waste Management Board. California, 2006.

[11] U.S Environmental Protection Agency, Characterization of Building Related Construction and Demolition Debris in United States, Municipal and Industrial Solid Waste Division, Office of Solid Waste, EPA530-R-98010, 1998.

[12] Environmental Protection Agency, European Waste Catalogue and Hazardous Waste List, Ireland, 2002.

[13] Environment Protection Authority, Waste Profile Study of Victorian Landfill, Golder Associates Pty Ltd. Australia, 1999.

[14] Gavilan, R.M. and Bernold, L.E., Source evaluation of solid waste in building construction. Journal of Construction Engineering and Management 120(3), pp. 536-552, 1994. 
[15] Ekanayake, L.L and Ofori, G., Building waste assessment score: a design base tool. Building and Environment, 39, pp. 851-861, 2004.

[16] Ruslin Hj. Hassan, Sistem Pengurusan Sampah Sarap di Dewan Bandaraya Kuala Lumpur: Isu dan Masalah, Policies to improve Municipal Solid Waste Management, eds. Siwar, C., Ali, H., Ahmad, A.R. \& Hamid, M.Z.A, LESTARI: UKM, pp. 19-26, 2001.

[17] Jamaluddin Md. Jahi, Issues and problems in management of solid waste by local authorities, Policies to improve Municipal Solid Waste Management, eds. Siwar, C., Ali, H., Ahmad, A.R. \& Hamid, M.Z.A, LESTARI: UKM, pp. 7-11, 2001.

[18] Kulatunga, U., Amaratunga, D., and Haigh, R., Attitudes and perceptions of construction workforce on construction waste in Sri Lanka, Management of Environmental Quality: An International Journal, 17(1), pp. 57-72, 2006. 